\title{
20 ЛЕТ НА СЛУЖБЕ ОТЕЧЕСТВЕННОМУ СТАНКОСТРОЕНИЮ
}

Отрасль станкостроительной и инструментальной промышленности к началу 90-х годов прошлого столетия была одной из ведущих отраслей народного хозяйства СССР и занимала второе место в рейтинге стран, производящих оборудование и инструмент. В эти годы особенно быстро наращивался выпуск прогрессивных высокопроизводительных станков и КПО с числовым программным управлением. К 1990 году объем выпуска металлообрабатывающего оборудования достиг более 80 тыс. шт. В том числе 22 тыс. станков и прессов с ЧПУ и 5 тыс. обрабатывающих центров и гибких производственных линий. Это, в свою очередь, требовало развитых кооперационных связей и привлечения огромного количества комплектующих изделий: ЧПУ, датчиков, электрооборудования, гидравлики и т.д.

Понятно, что осуществить это без координации и научного обеспечения предприятий отрасли было нереально. Поэтому в самом начале так называемой «Перестройки» и последующей ликвидации отраслевого министерства, по инициативе руководителей предприятий и организаций было учреждено государственное акционерное общество (ГАО) «Станкоинструмент» - как системный интегратор, который впоследствии был ликвидирован из-за распада СССР.

В Российской Федерации в 1992 году было зарегистрировано открытое акционерное общество «Компания «Росстанкоинструмент». Однако происходившие в тот период в экономике страны процессы, а именно проведение акционирования предприятий при отсутствии совершенной законодательной базы, не дали возможности развить ОАО «Компания «Росстанкоинструмент».

5 марта 1999 года была организована Ассоциация «Станкоинструмент», учредителями которой стали ОАО «Компания «Росстанкоинструмент», ОАО «Красный пролетарий» и ОАО «ВНИИИНСТРУМЕНТ». Тогда же, на собрании, был утвержден устав Ассоциации. C тех пор 5 марта традиционно считается днем рождения Ассоциации.

Родоначальниками создания нашей Ассоциации были Н. А. Паничев (президент ОАО «Компания «Росстанкоинструмент», министр станкостроительной и инструментальной промышленности СССР с 1986 по 1991 год), В.Н. Ефимов (начальник отдела новых технологий, внешних связей и выставочной деятельности ОАО «Компания «Росстанкоинструмент»), В.М. Лахтюхов и А.А. Наумов (заместители начальника отдела новых технологий, внешних связей и выставочной деятельности ОАО «Компания «Росстанкоинструмент»).

Первым генеральным директором Ассоциации стал В. Н. Ефимов, затем его

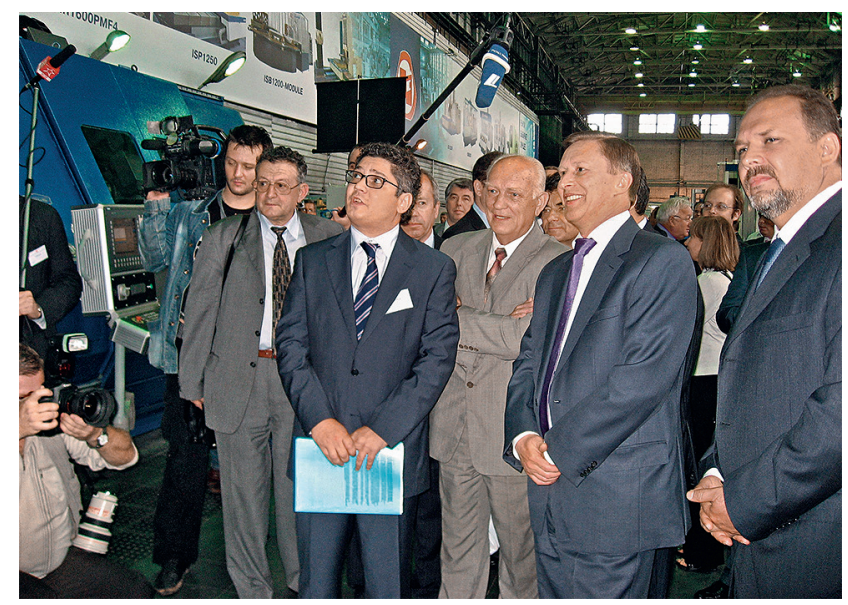

В центре - Николай Александрович Паничев 


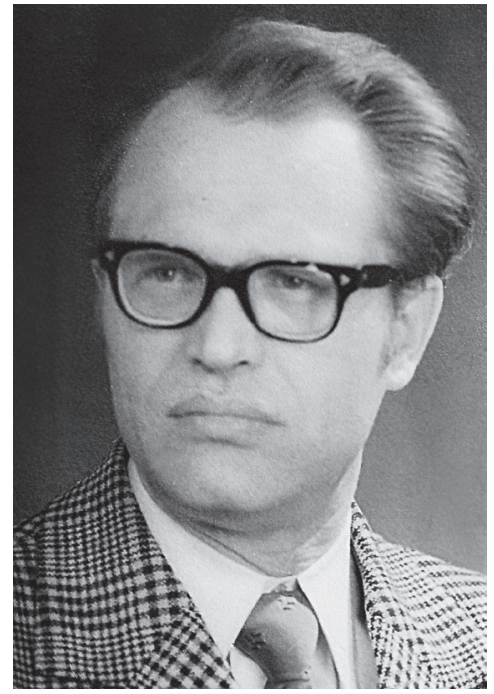

В.М. Лахтюхов сменил С.В. Васильев. В 2002 году президентом Ассоциации был избран Н. А. Паничев, которого в 2004 году сменил на этом посту Г. В. Самодуров, во3главляющий Ассоциацию в настоящее время.

В 2002 году начал действовать совет директоров, рассматривающий наиболее острые проблемы отрасли и дающий рекомендации по их решению. В состав совета директоров входят руководители ведущих предприятий отрасли. С 2002 года совет директоров возглавлял В. П. Исанин, передавший в 2004 году свои полномочия Н. А. Паничеву. В 2012 году председателем совета директоров избран Г. В. Боровский, а Н. А. Паничев назначен Почетным председателем совета директоров.

Первыми членами Ассоциации стали такие предприятия, как «Тяжпрессмаш», «Тяжмехпресс», «Сиблитмаш», «САСТА», «Донпрессмаш», «Ивановский ЗТС», «САВМА», «МИЗ», «Станкозавод Орджоникидзе» и др. - всего около 20 предприятий.

Сегодня Ассоциация производителей станкоинструментальной продукции «Станкоинструмент» объединяет более 160 предприятий и организаций, инжиниринговых компаний и научно-исследовательских институтов станкоинструментальной промышленности, которые создают продукцию

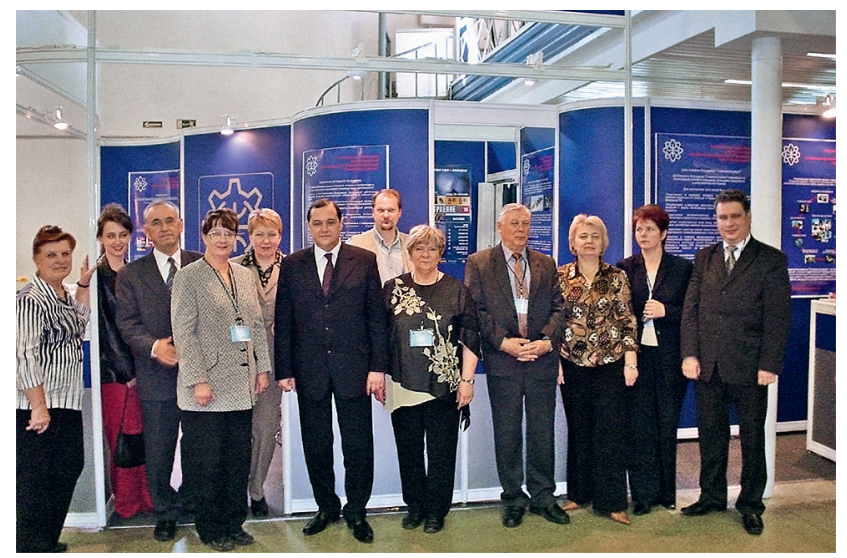

Коллектив Ассоциации производителей станкоинструментальной продукции «Станкоинструмент» и услуги в области инновационных технологий обработки материалов, разработки высокотехнологичных комплексов металлорежущего, кузнечнопрессового и литейного оборудования, инструмента, технологической оснастки и комплектующих изделий, измерительной техники, систем промышленной автоматизации, программного обеспечения.

Деятельность Ассоциации «Станкоинструмент» направлена на консолидацию усилий и повышение потенциала предприятий станкостроительной отрасли. На постоянной основе осуществляется взаимодействие с Советом Федерации РФ и Государственной Думой РФ по вопросам развития станкоинструментальной промышленности через комитеты и комиссии. Ассоциация «Станкоинструмент» очень тесно взаимодействует с Минпромторгом и Минэкономразвития в выработке и реализации мер государственной поддержки отрасли, в том числе Постановлений Правительства № 9 от 14 января 2017 года и № 719 от 17 июля 2015 года и Приказов Минпромторга РФ № 889 от 27 марта 2017 года, № 640 от 8 апреля 2014 года и № 4358 от 12 декабря 2017 года.

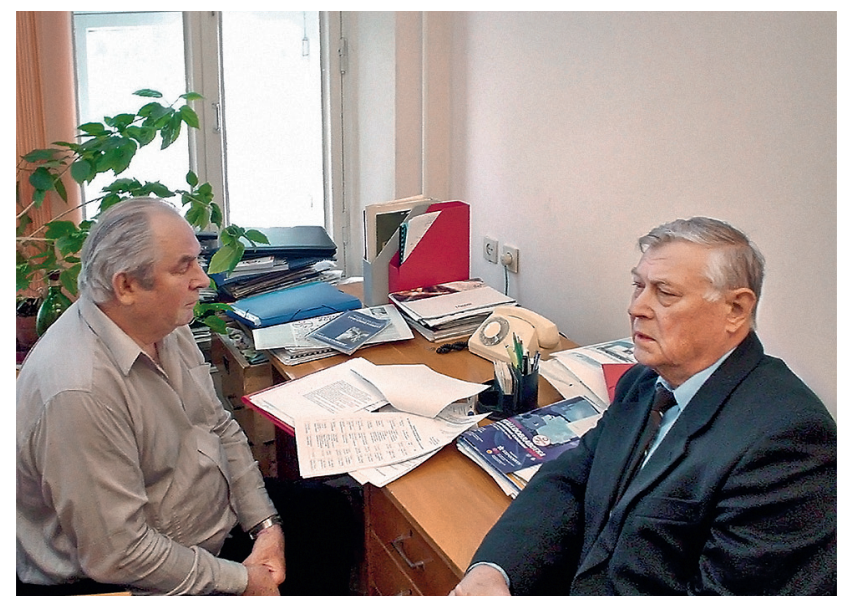

В. Н. Ефимов и А. А. Наумов

Ассоциация работает с общественными организациями: Общероссийской общественной организацией «Союз машиностроителей России» (ООО «СоюзМаш России»), Торгово-промышленной палатой РФ (ТПП РФ), Российским союзом промышленников и предпринимателей (РСПП), Российским союзом товаропроизводителей (РСТ), Общественной палатой РФ, Московской торговопромышленной палатой. Ассоциацией совместно с Торгово-промышленной палатой РФ, Союзом машиностроителей России, Российским союзом промышленников и предпринимателей ведется работа по обсуждению и доработке проектов федеральных законов, концепций, стратегий развития отечественного машиностроительного комплекса, оценке их регулирующего воздействия. 
Ассоциация «Станкоинструмент» является членом Торгово-промышленной палаты России. Президент Ассоциации входит в состав Совета ТПП РФ, Совета по промышленному развитию и конкурентоспособности экономики России при ТПП РФ.

Президент Ассоциации «Станкоинструмент» входит в состав Правления ОООР «Союз машиностроителей России», является председателем Комитета при Бюро ЦС Союзмаша по станкостроительной и инструментальной промышленности,

Ассоциация является членом Российского союза промышленников и предпринимателей, Московской торгово-промышленной палаты, Российского союза товаропроизводителей и взаимодействует с ними по актуальным вопросам развития отечественной экономики.

Совместная деятельность Ассоциации с общественными организациями позволяет формировать мнение представителей федеральных органов исполнительной власти, специалистов и экспертов по вопросам необходимости поддержки и развития отечественной станкоинструментальной отрасли. По результатам участия в круглых столах, конференциях, заседаниях комитетов и комиссий Ассоциация направляет предложения и замечания в Администрацию Президента РФ, Правительство РФ, Государственную Думу РФ, Минпромторг РФ и Минэкономразвития РФ, федеральные органы исполнительной власти.

Сотрудничество Ассоциации с администрациями регионов России осуществляется на основании заключенных с 22-мя регионами Соглашений о социально-экономическом и техническом сотрудничестве, целью которых является социальноэкономическое партнерство, направленное на сохранение и развитие производственного и научно-технического потенциала организаций машиностроения, согласование совместных усилий по разрешению проблем, стоящих перед организациями машиностроения.

Тесное взаимодействие осуществляется с предприятиями Ассоциации, выпускающими обрабатывающие центры, станки с ЧПУ, кузнечнопрессовое и литейное оборудование, все виды инструмента, проводится ежеквартальный мониторинг их деятельности, который во многом является основой для выработки и принятия решений по различным мерам поддержки.

Ассоциация взаимодействует с техническими университетами на базе заключенных соглашений, в рамках которых разрабатывались и утверждались планы совместных работ. Соглашения заключены с 16 вузами: МГТУ «СТАНКИН», Донской ГТУ, МГТУ им. Н. Э. Баумана, Петербургский ПУ Петра Великого, МГТУ «МАИ», Новосибирский ГТУ, Московский Политех и др.
Предприятия отрасли имеют договора на научные разработки и подготовку кадров более чем с 35-ю техническими университетами.

Совместно с техническими университетами Ассоциация обращалась в Минобразования РФ по различным вопросам подготовки специалистов, оказывала поддержку техническим университетам по вопросам новой формы обучения, нового статуса и т.п.

На выставках «Металлообработка» и «Технофорум» были организованы экспозиции «Наука, профильное образование, производство».

На выставках с участием Ассоциации проводились конференции по теме «Основные направления и методы подготовки специалистов в области металлообработки». Кроме того, научные работники вузов принимали участие с докладами в традиционных конференциях, проводимых Ассоциацией.

Ассоциация сотрудничает с 12 -ю российскими отраслевыми промышленными ассоциациями и объединениями машиностроительных отраслей промышленности. Заключенные соглашения предусматривают проведение скоординированных работ по следующим основным видам деятельности:

$\rightarrow$ созданию условий для разработки и реализации программ технического перевооружения предприятий и организаций, входящих в ОАО, на основе консолидации их научно-технического, инженерного потенциала;

$\rightarrow$ проведению выставок, семинаров, «круглых столов» и учебных курсов по вопросам производственной деятельности, передовым технологиям, новейшим видам оборудования, инструмента и т.П.;

$\rightarrow$ участию в создании и реализации региональных программ;

$\rightarrow$ участию в деятельности федеральных организаций;

$\rightarrow$ формированию условий и информационной среды, способствующих привлечению финансовых ресурсов банков и других источников в разработку и реализацию программ технического перевооружения предприятий и организаций.

Ассоциацией «Станкоинструмент» подписаны Меморандумы о сотрудничестве и взаимодействии с ведущими зарубежными станкостроительными ассоциациями, в том числе Германии, Швейцарии, Чехии, Италии, Республики Корея, Тайваня, Великобритании и т.д. Ключевыми пунктами меморандумов являются:

$\rightarrow$ обмен статистической информацией относительно развития национального станкостроительного производства;

$\rightarrow$ поддержка членов ассоциаций на внутренних и внешних рынках; 
$\rightarrow$ предоставление возможности принимать участие с коллективной экспозицией в национальных выставочных проектах;

$\rightarrow$ развитие долгосрочного сотрудничества между национальными производителями станочной продукции, членами национальных станкостроительных ассоциаций.

Станкостроение является технологической фондообразующей отраслью, без которой невозможно проведение модернизации промышленности. Передовые решения для модернизации российского машиностроительного комплекса представляет международная специализированная выставка «Оборудование, приборы и инструменты для металлообрабатывающей промышленности «Металлообработка».

Именно на этой выставке специалисты отрасли могут получать информацию о современных мировых тенденциях в создании нового оборудования и технологий обработки металлов.

Этот крупнейший в России и СНГ инновационный проект в области станкостроения ЦВК «Экспоцентр» реализует в партнерстве с Ассоциацией и при поддержке Совета Федерации Федерального Собрания РФ, Министерства промышленности и торговли РФ, Союза машиностроителей России. Отраслевой форум традиционно проходит под патронажем Торгово-промышленной палаты РФ и правительства Москвы.

Выставка «Металлообработка» проводилась с 1984 года один раз в два года (по четным годам). В новых экономических условиях она сохранила свой авторитет в органах власти, профессиональных кругах и представляет собой визитную карточ-

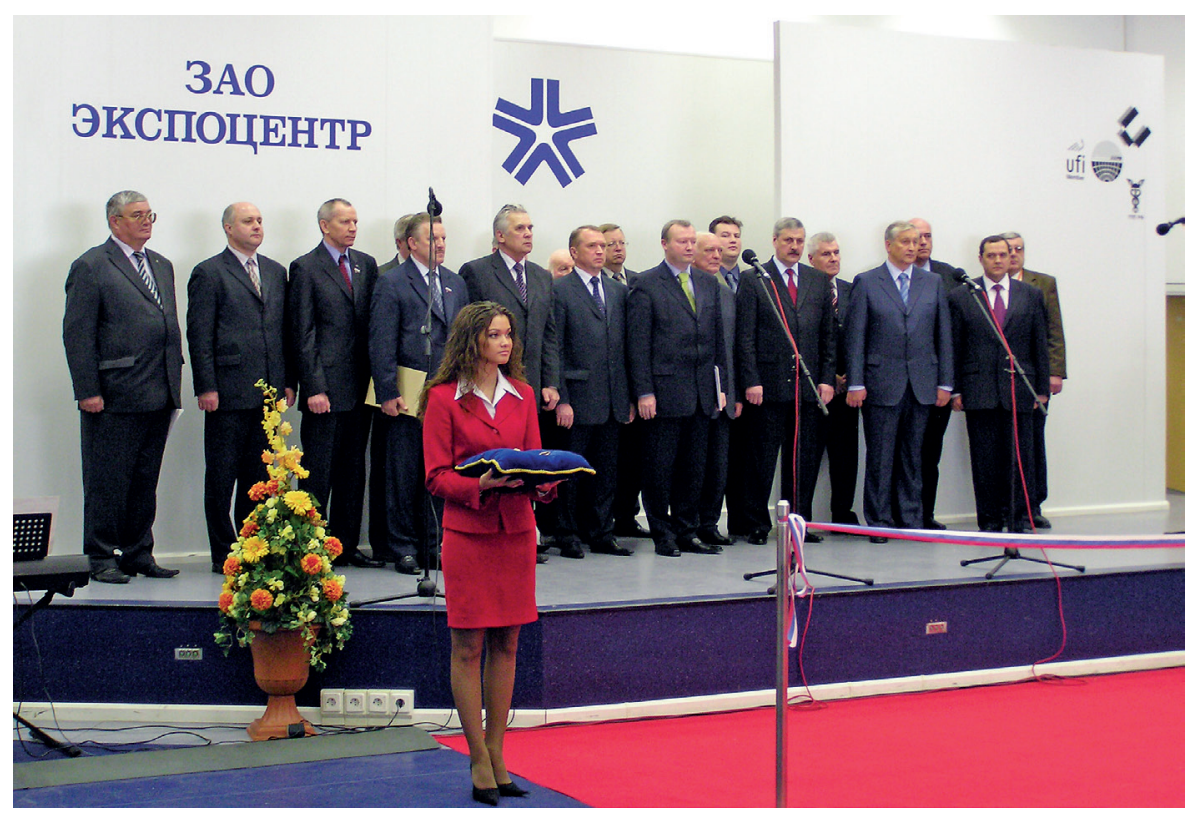

Церемония открытия выставки «Металлообработка» ку современной станкостроительной отрасли страны. Начиная с 2010 года «Металлообработка» с успехом проходит на площадке ЦВК «Экспоцентр» уже ежегодно.

Международное признание отраслевого форума подтверждено знаками Всемирной ассоциации выставочной индустрии (UFI) и Российского союза выставок и ярмарок (РСВЯ). Выставка пользуется заслуженным авторитетом среди мировых производителей металлообрабатывающего оборудования. Нет сомнений, что выставка дает новый импульс развитию машиностроительного комплекса, в частности, инновационного станкостроения в России с активным использованием механизмов международной кооперации, привлечением инвестиций, организацией совместных производств.

Согласно рейтингу ТПП РФ и РСВЯ, «Металлообработка» признана лучшей выставкой России по тематике «Машиностроение, металлообработка, станки, промышленное оборудование» во всех номинациях: «Международное признание», «Профессиональный интерес», «Охват рынка», «Выставочная площадь». Все выставочные показатели подтверждены официальным выставочным аудитом.

Продвигая в отечественное машиностроение самые передовые технологические решения, выставка «Металлообработка» способствует формированию в России инновационной экономики, ускоряет превращение актуальных высокотехнологичных разработок в рыночный продукт и внедрение этого продукта во все отрасли промышленности.

Ассоциация тесно сотрудничает с отраслевыми специализированными журналами: «ИТО», «РИТМ», «Умное производство», «Металлист Евразии» и др.

При поддержке Ассоциации ежеквартально издается отраслевой научно-технический журнал «СТАНКОИНСТРУМЕНТ» с освещением проблем импортозамещения, научных, прикладных и законодательных вопросов станкостроения и производства инструмента, вопросов стандартизации, измерений и метрологического обеспечения, экономики станкостроения, рынка станков и инструмента, подготовки кадров.

20 лет деятельности Ассоциации «Станкоинстру- 
мент» на деле продемонстрировали ее авторитет и способность грамотно и эффективно осуществлять главную функцию по защите интересов своих членов и быть центром по взаимодействию предприятий в масштабах отрасли.
Исполнительная дирекция Ассоциации выражает свою признательность и благодарность предприятиям и организациям, являющимся членами Ассоциации, за сотрудничество в нашем общем деле - развитии отечественного станкостроения.

\section{ГОВОРЯТ УЧАСТНИКИ И ПАРТНЕРЫ АССОЦИАЦИИ «СТАНКОИНСТРУМЕНТ»}

\section{АО «Экспоцентр»}

Руководство и коллектив «Экспоцентра» поздравляет Ассоциацию «Станкоинструмент» с 20-летием с момента создания!

За прошедшие два десятилетия Ассоциация производителей станкоинструментальной продукции «Станкоинструмент» смогла утвердиться в качестве ведущего отраслевого объединения российских станкостроителей.

0бъединив более 160 предприятий и организаций, инжиниринговых компаний и научно-исследовательских институтов станкоинструментальной промышленности, Ассоциация стала за эти годы одним из крупнейших отраслевых партнеров правительства по реализации программ развития отечественной станкоинструментальной отрасли. Ее предложения весомо звучат в органах исполнительной и законодательной власти Российской Федерации, направляются в Администрацию Президента РФ, к ним прислушиваются в профильных федеральных министерствах.

Давнее и тесное сотрудничество объединяет Ассоциацию «Станкоинструмент» и Центральный выставочных комплекс «Экспоцентр». Можно сказать, что история этой долгой деловой дружбы началась до 1999 года, до того как была учреждена Ассоциация, и уходит своими корнями в 80-е годы прошлого века. Именно тогда в «Экспоцентре» впервые прошла международная выставка «Металлообработка» (1984), которую поддерживало Министерство станкостроительной и инструментальной промышленности СССР.

Менялись государственные структуры, на смену им приходили акционерные компании, но люди, заложившие основы обновленной станкостроительной отрасли и главной отраслевой станкостроительной выставки страны, продолжали начатое дело с полным пониманием своей профессиональной и гражданской ответственности за судьбы отечественного станкостроения. Так сложился прочный выставочно-отраслевой союз Ассоциации «Станкоинструмент» и «Экспоцентра», позволивший вывести смотр «Металлообработка» на по-

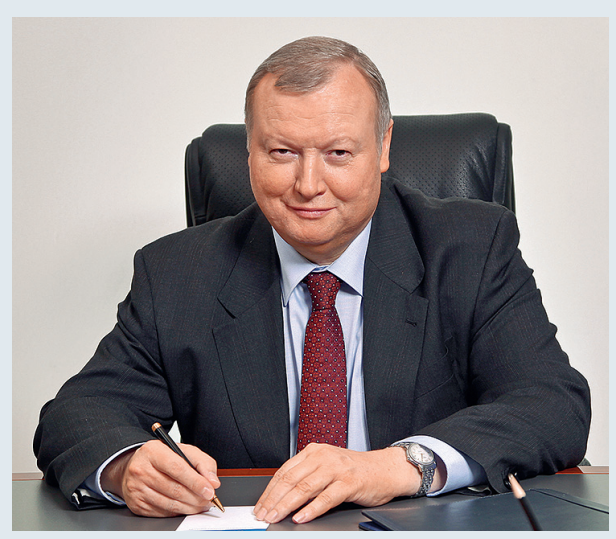

Сергей Сергеевич Беднов

зицию беспрекословного лидера, которая уверенно сохраняется выставкой и поныне.

«Металлообработка» сегодня - это почти 1100 компаний-экспонентов из 33 стран мира, из которых почти половина - отечественные; это более 41 тыс. квадратных метров экспозиционных площадей, наполненных новейшими станками и технологиями, уникальными, невероятными еще вчера возможностями обработки материалов; это более 30 тыс. посетителей-специалистов, а также безусловное признание огромной популярности и лидерства среди выставочных мегапроектов в России и Восточной Европе.

Знаки Всемирной ассоциации выставочной индустрии (UFI) и Российского союза выставок и ярмарок (РСВЯ) - наглядная демонстрация международного признания смотра. Согласно рейтингу ТПП РФ и РСВЯ «Металлообработка» признана лучшей выставкой России по тематике «Машиностроение, металлообработка, станки, промышленное оборудование» во всех номинациях: «Международное признание», «Профессиональный интерес», «0хват рынка», «Выставочная площадь». Все выставочные показатели подтверждены официальным выставочным аудитом.

Можно реализовать инновационные программы в любой сфере производства, но нельзя игнорировать тот очевидный факт, что станкостроение было, есть и будет основной технологической фондообразующей отрас- 
лью, без которой невозможно проведение модернизации промышленности. Продвигая в отечественное машиностроение самые передовые технологические решения, Ассоциация «Станкоинструмент» совместно с «Экспоцентром» и выставочным проектом «Металлообработка» способствует формированию в России инновационной экономики, ускоряет превращение актуальных высокотехнологичных разработок в рыночный продукт и внедрение этого продукта во все отрасли промышленности.

В связи с 20-летием Ассоциации производителей станкоинструментальной продукции «Станкоинструмент» хочу от лица коллектива «Экспоцентра» по- желать руководству отраслевого объединения, всем руководителям предприятий - участников Ассоциации «Станкоинструмент», инженерам и специалистам станкостроительных предприятий России успешной реализации производственных программ, непременного и стабильного роста спроса на производимую продукцию, обеспечивающего экономическое процветание и развитие, новых дерзновенных планов на будущее и возможностей их реализации, крепкого здоровья, счастья и благополучия.

\section{Генеральный директор АО «Экспоцентр» Беднов Сергей Сергеевич}

\section{Московский инструментальный завод}

Московский инструментальный завод является современным высокооснащенным предприятием по выпуску прецизионного зуборезного и резьбообразующего инструмента, а также твердосплавного резьбонарезного инструмента. Коллектив ПАО «МИЗ» готовится достойно отметить 100-летие завода.

Последствия кризиса, охватившего нашу страну в 90-е годы, не могли не сказаться на деятельности Московского инструментального завода, но коллективу удалось разработать и реализовать срочные меры по выходу завода из кризиса, ликвидировать имеющуюся задолженность и оздоровить финансовое положение, сохранить в основном номенклатуру выпускаемой продукции, определить пути своего дальнейшего развития.

В то же время, ввиду неготовности российской промышленности к работе в рыночных условиях, станкоинструментальная отрасль вместе со всем машиностроением оказалась в трудном положении. Разрыв хозяйственных связей, острый недостаток оборотных средств, спад производства привели к банкротству и прекращению производственной деятельности многих предприятий бывшего Минстанкопрома.

Разрушилось существовавшее тесное сотрудничество между предприятиями станкоинструментальной отрасли, с потребителями продукции по многим хозяйственным и техническим направлениям.

В этот сложный для отрасли период была образована российская Ассоциация производителей станкоинструментальной продукции «Станкоинструмент», которая в этом году отмечает свое двадцатилетие.
Основными задачами созданной Ассоциации стали разработка и реализация мер по восстановлению утраченного потенциала, возрождение отраслевой науки, координация деятельности предприятий отрасли, продвижение интересов отрасли в государственных структурах, активизация инновационной деятельности.

Ассоциация организовала постоянный обмен опытом, в том числе с посещением крупных предприятий отрасли. Подписан ряд правительственных документов, представители Ассоциации принимают участие в деятельности рабочих групп, комиссий Минпромторга России, направленных на развитие отрасли. Многие станкоинструментальные предприятия получили бюджетное финансирование для проведения НИОКР. Организован постоянный обмен информацией о текущей производственной деятельности предприятий.

Ежегодно организуются тематические выставки: «Машиностроение» и «Металлообработка», в которых принимают участие ведущие отечественные и зарубежные предприятия отрасли.

Московский инструментальный завод принимает активное участие в мероприятиях, проводимых Ассоциацией, представитель завода многие годы входит в состав совета директоров Ассоциации.

Поздравляем коллектив Ассоциации и предприятия, входящие в ее состав, с двадцатилетием и желаем дальнейшей плодотворной работы на благо сохранения и укрепления станкоинструментальной отрасли!

Заместитель генерального директора ПАО «Московский инструментальный завод» Помазков Виктор Иванович 


\section{АО «Стан-Самара»}

Традиционно на рынке станочной продукции «СтанСамара» предлагает координатно-расточные и координатно-шлифовальные станки, отделочно-расточные полуавтоматы, накладные поворотные столы, а также приводные и электрошпиндели.

Вся новая продукция предприятия относится к классу точности «С»- особо высокой точности.

Непривычно малые для отечественной промышленности размеры и скромные по сравнению с гигантами объемы производства не мешают сегодня заводу «Стан-Самара» занимать свое место среди членов Союза машиностроителей России, Торгово-промышленной палаты и Союза работодателей Самарской области. Но особое значение мы придаем членству в Ассоциации «Станкоинструмент», в которую вступили в далеком 2000 году. Именно этот момент явился поворотным в нашей истории, и именно благодаря этому мы начали ощущать себя полноправными членами профессионального сообщества.

Организуемые Ассоциацией выставки «Металлообработка», сначала в Сокольниках, а впоследствии на Красной Пресне, не представляются нам без самого деятельного участия вице-президента М.В.Федоровой, чьи советы и рекомендации помогали нам. Она привела нас на выставку и ей мы обязаны тем, что уже третье десятилетие являемся экспонентом этого получившего международное признание московского форума.

В составе делегации Ассоциации наши представители неоднократно посещали организуемые ино-

\section{Станкозавод «ТБС»}

Станкозавод «ТБС» является ведущим предприятием отрасли в Северо-Западном регионе России, обладающим высоким собственным потенциалом производственной деятельности по выпуску современных станков среднего и тяжелого класса, способным организовать системную работу по перевооружению промышленных предприятий.

С 2004 года, после вступления «ТБС» в Ассоциацию «Станкоинструмент», наши организации успешно и плодотворно сотрудничали по ряду вопросов.

Например, при участии Союза промышленников и предпринимателей Санкт-Петербурга и Российской странными коллегами-станкостроителями международные мероприятия в Германии, Италии, Японии и других странах. Важность и необходимость этих поездок для определения перспективных направлений собственной работы очевидны, а безупречная организация и администрирование их директором по рекламно-выставочной деятельности А. В. Мандрабурой позволяют уделять максимальное внимание непосредственно работе.

Те, чья деятельность связана со станками и инструментом, высоко ценят членство в Ассоциации и ряды ее постоянно пополняются известными и не очень организациями. В этих условиях мы считаем самым важным укрепление связей между предприятиями, непосредственно производящими продукцию, хотя нас не так много, как хотелось бы, не все мы знакомы друг с другом, с трудом кооперируемся и каждый работает фактически лишь в своей нише. И часто лишь благодаря вице-президенту В.М. Ивахову, который знает всех изготовителей, бывает на заводах и постоянно общается с каждым из нас, становятся известны индивидуальные и сводные ключевые экономические показатели, а многие общие вопросы решаются намного легче.

Мы гордимся тем, что являемся частью станкостроительного сообщества нашей страны - Ассоциации «Станкоинструмент», и в канун двадцатилетия желаем Ассоциации дальнейшего роста, а ее членам - успешной работы на благо России.

\section{Генеральный директор ЗАО «Стан-Самара» Царфин Авдим Нисонович}

Ассоциации производителей станкоинструментальной продукции «Станкоинструмент» на базе «ТБС» был учрежден «Технологический центр металлообработки Северо-Западного региона». Целью деятельности центра стало объединение специализированных предприятий, обеспечивающих комплексное решение проблем промышленности по всем составляющим: технология, оборудование, финансы.

Благодаря усилиям Н. А. Паничева и Г. В. Самодурова были налажены связи с государственными структурами и органами власти.

Важную роль в продвижении оборудования и услуг, предоставляемых «ТБС», сыграла информационная поддержка Ассоциации «Станкоинструмент», 
а также совместное участие в выставках, семинарах и конференциях. Содействие в этих вопросах многие годы осуществляли М. В. Федорова, В.М. Ивахов и А. В. Мандрабура.

Тесное взаимодействие с членами Ассоциации «Станкоинструмент», такими как Omron Electronics, Balluff, «Балт Систем», «КоСПА», «Модмаш-Софт», Renishaw, Siemens, «Стан-Самара», УзТС, Fanuc, Heidenhain и др., позволило нам сформировать надежную базу поставщиков комплектующих, литья, инструмента.

Уже 20 лет Ассоциация занимается очень нужным и важным делом. Хочется поздравить весь коллектив с этой торжественной датой.

Выражаем слова особой благодарности за неравнодушное и творческое отношение к работе руководству и сотрудникам. Пусть это знаменательное событие станет настоящим праздником для тех, кто все эти годы трудился в коллективе, сохраняя и приумножая традиции, используя обретенный опыт. Творческий подход, сплоченность и слаженность вашей команды в работе помогут воплотить новые идеи и впредь послужат надежной гарантией процветания не только Ассоциации, но и ее членов.

Примите слова признательности за энтузиазм, стремление мастерски справляться с задачами любой сложности.

Желаем вам и впредь быть дружной командой, никогда не останавливаться на достигнутом и с новыми творческими силами идти навстречу успехам. Многих вам радостей и удач в жизни, ярких свершений и всего наилучшего!

\section{Генеральный директор 000 «Станкозавод «ТБС» Ладыгин Константин Владимирович}

\section{«Томский инструмент»}

Компания «Томский инструмент», основным производственным подразделением которой является 000 «Томский инструментальный завод», обладает полным объемом функциональных возможностей по производству металлорежущего инструмента: от исследования рынка, проектирования и технологической подготовки производства до закупок материалов, входного контроля, производства и сбыта продукции.

В судьбе Томского инструментального завода как в капле воды отразились все перипетии постперестроечной эпохи. И в том, что завод жив и успешно развивается, немалая заслуга российской Ассоциации производителей станкоинструментальной продукции «Станкоинструмент», которая отмечает в этом году свое двадцатилетие.

Томский инструментальный завод сотрудничает с Ассоциацией с 2000 года.

Совместно пройден немалый путь, история Ассоциации - это история борьбы, преодолений и побед!

Уникальный сплав опыта организаторов и руководителей, патриотизма и желания трудовых коллективов работать доказали свое право на жизнь, право влиять на судьбу страны!

Умение вовремя повлиять на органы власти, разработать и внедрить многочисленные программы поддержки станкоинструментальной отрасли, заставить их успешно работать... Скольких лет и скольких сил это стоило!

Благодаря неоценимой информационной и методической поддержке Ассоциации наш завод смог принять участие в ряде федеральных целевых программ, найти нужные контакты в органах власти для помощи в преодолении кризисных ситуаций, получить финансовую поддержку в виде займа Российского фонда технологического развития. И, конечно, участие завода в Ассоциации дает возможность получать самое важное для развития бизнеса - многочисленные профессиональные контакты внутри и за пределами отрасли!

Наша Ассоциация - детище Почетного президента Николая Александровича Паничева, а затем принявшего эстафетную палочку президента Ассоциации Георгия Васильевича Самодурова, - это одна из самых уважаемых и влиятельных общественных организаций в Российском машиностроении! От скольких людей, казалось бы, далеких от нужд промышленности доводилось слышать: «Ассоциация «Станкоинструмент»? Конечно, знаем!»

От всей души поздравляем дорогих коллег с 20-летием основания Ассоциации!

С наилучшими пожеланиями,

Директор 000 «Томский инструментальный завод» Шварцев Сергей Григорьевич

Председатель совета директоров 000 НПК ТЭТа Семенов Григорий Валерьевич 


\section{ПОЗДРАВЛЕНИЯ ИНОСТРАННЫХ АССОЦИАЦИЙ}

\section{CECIMO}

Dear friends of STANKOINSTRUMENT,

On behalf of CECIMO, I would like to send you my warmest wishes for the 20th anniversary of your association. I congratulate you on the many achievements and success reached in the past 20

\section{The Association For Manufacturing Technology}

Dear Mr. Samodurov and Colleagues,

AMT, The Association For Manufacturing Technology, extends our sincere congratulations on the 20th anniversary of your association. From your inception in 1999, STANKOINSTRUMNENT has played a key role in consolidating and developing the machine tool sector of the Russian manufacturing industry. Due in no small part to your efforts, Russia has become a strong player at home and abroad in the manufacturing technology

\section{CMTBA}

Dear Friends -

On the occasion of Russian Association of machine-tool manufacturers «STANKOINSTRUMNENT» establishing 20 years, I extend my warmest congratulations to Russian friends on behalf of China Machine Tool \& Tool Builders' Association!

Having been supporting and cooperating, Peers from both countries in the machine tool \& tool industry have

\section{IMTMA}

Dear Mr. Samodurov,

I extend my heartiest congratulations to Stankoinstrument for completing 20 glorious years of success in serving the interests of Russian manufacturers. Your Association has always been on the top of the list at consolidating the efforts and increasing the potential of the enterprises of machine tool industry.

\section{TMBA}

Поздравляем Вас с 20-летним юбилеем создания ассоциации и желаем Вам дальнейшего развития. years, and we look forward to a continuous and fruitful cooperation.

Yours sincerely,

\section{Filip Geerts, Secretary General CECIMO}

market, an important aspect of continuing to develop a strong, efficient, and high quality manufacturing base.

For all of this, we applaud all STANKOINSTRUMNENT members and the association leaders.

We wish you continued success as you move forward. With best wishes,

\section{Edward Christopher, Vice President, Global Services AMT - The Association For Manufacturing Technology}

achieved substantial results over along with the said period. I firmly believe that the existing cooperation between us will be cherished and go further and further pushed by both sides in the years to come!

Let's make joint effort to better serve our members to make great contribution to the machine tool industry for both countries!

With our best wishes!

Mao Yufeng

India has always worked closely with Russian companies on many fronts. We foresee a greater relationship in trade tie-ups particularly in the machine tool industry in the years to come.

Wishing you all the success.

\section{Anbu, Director General \& CEO Indian Machine Tool Manufacturers' Association}

Congratulations on your 20th anniversary and best wishes for continued success..

Jui-HsiungYen. Chairman of TMBA 


\section{Verein Deutscher Werkzeugmaschinenfabriken VDW}

Greeting address for the 20th anniversary of the Russian Machine Tool

Association Stankoinstrument

From association to association: The VDW (German Machine Tool Builders' Association) congratulates its Russian partner association Stankoinstrument on its 20th birthday.

Both associations have been working together closely from the very beginning. There were regular face-to-face meetings in Moscow to discuss common interests and,

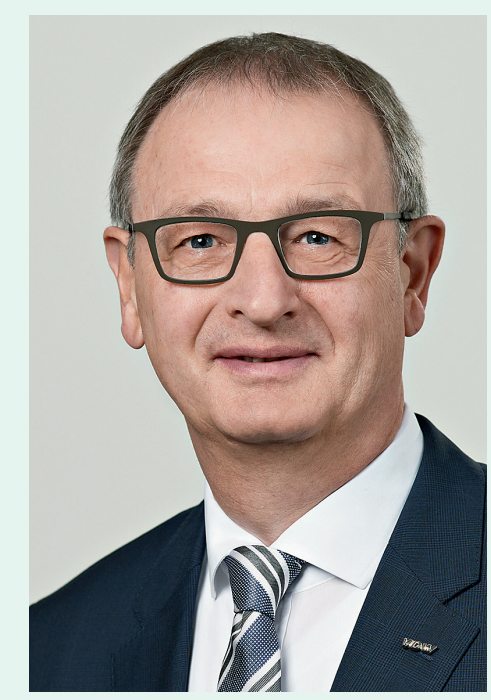
organiser of Metalloobrabotka, the leading Russian trade fair for metalworking. The German machine tool industry has been active there with a German pavilion for over 30 years. Even though the political conditions are currently making business very difficult, we want to maintain this commitment. In May of this year, we will again be present with more than 100 companies at the joint stand alone. We are convinced that a good partnership is beneficial for both sides. The Soviet Union and later Russia has always been a very important market with great potential for our companies.

The cooperation in terms of trade fairs is of course not a one-way street. Stankoin-strument is also a regular guest at EMO Hannover, if possible, to define projects. Topics were joint ventures, co-operations, joint research projects or cooperation in training. Whenever we needed in-depth expertise on the industry in Russia, Stankoinstrument was always available to establish contacts, for example with representatives of Stankin University in Moscow.

The most important cooperation is undoubtedly in the field of trade fairs. Stankoin-strument is co-

\section{Ассоциация машиностроительных технологий}

Президенту ассоциации «Станкоинструмент»

Госп. Г.В. Самодурову

Уважаемый Георгий Васильевич!

Позвольте мне поздравить Вас и в вашем лице всех сотрудников возглавляемой Вами Ассоциации «Станкоинструмент», которая в этом году отмечает прекрасную годовщину 20-летие.

Мне очень приятно отметить, что прошедшие годы были ознаменованы дальнейшим укреплением связей между Ассоциацией машиностроительных технологий Чешской Республики и ассоциацией «Станкоинструмент», с которой нас связывает многолетнее сотрудничество.

С большим удовольствием хочу, уважаемый Георгий Васильевич, подчеркнуть Ваш огромный личный вклад в развитие сотрудничества между машиностроителями наших стран. the world's leading trade fair for metalworking, to present the Russian machine tool industry. So next time is in September of this year. We are very much looking forward to welcoming the world machine tool industry in Germany and to being once again a good host for Russian exhibitors and visitors.

\section{Dr. Wilfried Schäfer, Executive Director of the VDW}

При посещении Чешской экспозиции на прошлой выставке «Металлообработка 2018», Вы смогли опять убедиться, что машиностроители Чехии достигли такого уровня производства, который позволяет им успешно конкурировать с ведущими мировыми производителями. И что особенно важно, чешские машиностроительные предприятия стремятся сохранить свои позиции на российском рынке и твердо намерены развивать и углублять сотрудничество со своими российскими коллегами.

Позвольте мне, уважаемый Георгий Васильевич, пожелать Вашей Ассоциации «Станкоинструмент» много успехов и выразить надежду на дальнейшее развитие нашего сотрудничества.

С глубоким уважением,

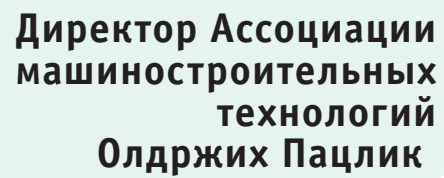

